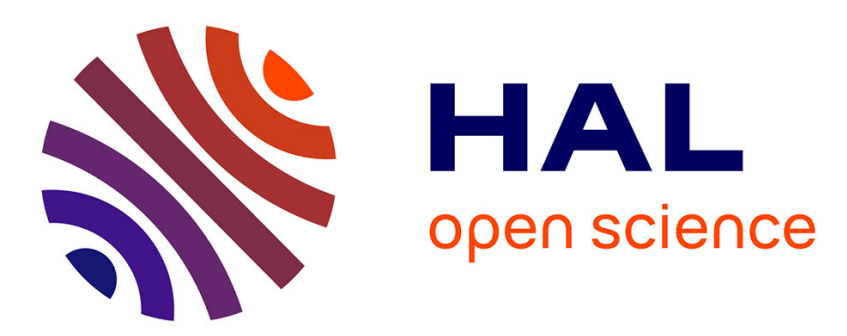

\title{
Temporary $\mathbf{N}$ starvation in maize (Zea mays L.) : effects on development, dry matter accumulation and grain yield
}

Philippe Girardin, Matthys Tollenaar, Arnaud Deltour, Joseph Muldoon, J.-L. Meyer

\section{To cite this version:}

Philippe Girardin, Matthys Tollenaar, Arnaud Deltour, Joseph Muldoon, J.-L. Meyer. Temporary N starvation in maize (Zea mays L.) : effects on development, dry matter accumulation and grain yield. Agronomie, 1987, 7 (4), pp.289-296. hal-00884993

\section{HAL Id: hal-00884993 https://hal.science/hal-00884993}

Submitted on 1 Jan 1987

HAL is a multi-disciplinary open access archive for the deposit and dissemination of scientific research documents, whether they are published or not. The documents may come from teaching and research institutions in France or abroad, or from public or private research centers.
L'archive ouverte pluridisciplinaire HAL, est destinée au dépôt et à la diffusion de documents scientifiques de niveau recherche, publiés ou non, émanant des établissements d'enseignement et de recherche français ou étrangers, des laboratoires publics ou privés. 


\title{
Temporary $\mathrm{N}$ starvation in maize (Zea mays L.) : effects on development, dry matter accumula- tion and grain yield
}

\author{
Philippe GIRARDIN, Matthys TOLLENAAR (*), Arnaud DELTOUR $\left({ }^{* *}\right)$ \& Joseph MULDOON $\left(^{*}\right)$ \\ with the technical assistance of J.-L. MEYER \\ I.N.R.A., Station d'Agronomie, B.P. 507, Centre de Recherches de Colmar, F 68021 Colmar \\ (*) Department of Crop Science, University of Guelph, Guelph, Ontario NIG2WI Canada \\ (**) Station Expérimentale FNPPPT, B.P. 56, F 29220 Landerneau
}

\begin{abstract}
The objective of this study was to determine sensitive periods of $\mathrm{N}$ deprivation for maize plants grown in pails, in a growth chamber or outside, irrigated with nutrient solution. Data on leaf and root development, dry matter accumulation and grain yield were collected. Generally, plant development was less affected by N starvation than plant dry matter accumulation. Leaf number was not influenced by $\mathrm{N}$ withdrawal from nutrient solution at any time. The only developmental parameter which was affected was the time between anthesis and silking. This was as high as 11 days when the $\mathbf{N}$ deprivation occurred during the first month after sowing. In this case the maturity was delayed by 15 to 21 days in comparison with the control plants. A deficiency in $\mathrm{N}$ availability, when $\mathrm{N}$ requirements were very high ( 3 to 4 weeks before silking) could be compensated for by $\mathrm{N}$ remobilization from the stem or older leaves to developing organs. When $\mathrm{N}$ deprivation occurred just after silking, grain yield of $\mathrm{N}$-starved plants was not affected by this temporary $\mathrm{N}$ deficiency. The response of maize to $\mathrm{N}$ deficiency may be explained by the ability of the maize plant to remobilize nitrogen from older organs to developing organs.
\end{abstract}

Additional index words : Harvest index, leaf area, root number, root/shoot ratio, yield components.

Privations d'azote chez le maïs : effets sur le développement, l'accumulation de matière sèche et le rendement en grains.

L'objectif de cette étude était de déterminer les périodes sensibles au manque d'azote pour des maïs cultivés en pots, en chambre de culture ou à l'extérieur, alimentés par une solution nutritive. Des mesures concernant le développement foliaire et racinaire, la production de matière sèche et le rencement en grains ont été effectués. En général, le développement du maïs était moins affecté par des privations d'azote que la production de matière sèche. Le nombre de feuilles n'était pas influencé par une alimentation dépourvue d'azote, et cela, quelle que soit la période d'application du traitement sans azote. Un manque d'azote pendant 8 jours durant le premier mois de végétation entraînait un allongement de la phase début de pollinisation - sortie des soies. Dans ce cas, la maturité était retardée de 15 à 21 jours par rapport au témoin. Lorsque les besoins en azote étaient intenses (3-4 semaines avant floraison), une déficience en cet élément dans l'alimentation du maïs pouvait être compensée en partie par une remobilisation de l'azote provenant de la tige et des feuilles âgées vers les organes en croissance. Le rendement en grains n'était pas affecté par un manque d'azote se produisant juste après la sortie des soies. Une alimentation totalement dépourvue d'azote pendant le dernier tiers du cycle végétatif entraîne une baisse de rendement en grain de 23 p. 100.

Mots clés additionnels : Indice de récolte, surface foliaire, nombre de racines, rapport racines/partie aérienne, composantes du rendement.

\section{INTRODUCTION}

The effects of $\mathbf{N}$ fertilization on yield of maize are well documented. However, opinions are divergent concerning the best way to obtain maximum uptake efficiency. On the one hand, some researchers show a high sensitivity of dry matter yield to summer sidedressing (OLSON et al., 1964 ; WELCH et al., 1971 ; MILLER et al., 1975), the major part of the $\mathrm{N}$ fertilizer being applied when the maize root system occupies the maximum volume of soil. On the other hand, STEVENSON \& BALDWIN (1969), and ANDERSON et al. 
(1982) reported that maize receiving a spring preplant $N$ application yielded as much grain as maize receiving sidedressed nitrogen. Some studies have suggested taking into account the $\mathrm{N}$-mineral residue carryover from previous crops (OLSON et al., 1976), as was proposed for winter wheat by the new french calculations on $\mathrm{N}$ fertilization rate (RÉMY \& VIAUX, 1983). Whatever techniques of $\mathrm{N}$ applications used, we have to take into account their eventual effects on environmental pollution.

$\mathrm{N}$ deprivation at different developmental phases of maize is a good way to determine the sensitive periods of $\mathrm{N}$ deprivation of the plant. The effects of nitrogen deficiency on yield of maize have already been studied (CARLES et al., 1957 ; VIETS, 1965 ; THOM \& WATKINS, 1978 ; BIGERIEGO et al., 1979) in order to adapt the nitrogen fertilization to the plant's requirements. These studies showed that the $\mathrm{N}$ uptake is highest between the 5-6 leaf and during the silking period. In addition, with almost all classical agricultural techniques, nitrogen can be applied only before the 8 leaf stage. Generally, the measurements were limited to grain yield, so that there is little information on changes in crop development and physiological characteristics resulting from temporary $\mathrm{N}$ starvation which could explain the decline of grain yield. With POWER (1971), we could think N deficiency probably restricts dry matter accumulation mostly during periods of high rates of dry matter accumulation.

The objective of this study was to determine the effects of $\mathrm{N}$ deprivation on the growth and development parameters and yield components. A more comprehensive understanding of $\mathrm{N}$ uptake and grain yield relationships is important for the improvement of $\mathrm{N}$ fertilization practices. The words deficiency, starvation, deprivation, depletion will be used and all will have the same meaning: absence of nitrogen in nutrient solution. The word stress will indicate the effects of this treatment on maize plants.

\section{MATERIALS AND METHODS}

This investigation consisted of three different experiments with maize grown in pails. The first experiment was carried out in a growth room of the University of Guelph, Ontario, Canada. The second was conducted in the field at the Cambridge Research Station $\left(43^{\circ} 7 \mathrm{~N}\right.$, $200 \mathrm{~m}$ elevation), Ontario, Canada, and the third was conducted at Colmar, France $\left(48^{\circ} 3 \mathrm{~N}, 200 \mathrm{~m}\right.$ elevation), in an area which could be covered by a moveable roof to prevent rainfall affecting the $\mathrm{N}$ concentration of the circulating nutrient solution. The french cultivar Limagrain LG 11 was used at each location.

\section{A. Experiment 1}

The experiment was carried out in a controlledenvironment growth room (GIRARDIN et al., 1985a). Treatments consisted of plants growing in turface irrigated with nutrient solution with or without nitrogen. Watering with $\mathrm{N}$-free solution began on the
18 th, 28th, 38th, 48th, 58th and 68th day after sowing (fig. 1A) and normal nutrient solution was resupplied after 10 days. These treatments are thereafter referred to as treatments 1.1 through 1.6. Other details of the experiment have been described previously (GIRARDIN et al., 1985a).

\section{B. Experiment 2}

Maize plants were grown at Cambridge Research Station in a nutrient culture system in the field (TOLlENAAR \& Migus, 1984). Plants were grown in pails filled with Turface similar to that used in Experiment 1. Pails were positioned in double rows $0.36 \mathrm{~m}$ apart and $1.10 \mathrm{~m}$ between double rows; the plant density was 79000 plants ha-1. Four seeds were sown in each pail at the end of May and thinned to 2 plants per pail 2 weeks later. The $\mathrm{N}$-deprived nutrient solution was the same as in Experiment 1. The normal nutrient solution (with nitrogen) consisted of $150 \mathrm{~g} \mathrm{28.14.14}$ water soluble fertilizer, $100 \mathrm{~g} \mathrm{MgSO}_{4}, 7 \mathrm{H}_{2} \mathrm{O} ; 75 \mathrm{~g}$ $\mathrm{Ca}\left(\mathrm{NO}_{3}\right)_{2}, 4 \mathrm{H}_{2} \mathrm{O} ; 0.2 \mathrm{~g} \mathrm{ZnSO}_{4}, 7 \mathrm{H}_{2} \mathrm{O}$ and $0.02 \mathrm{~g}$ $\mathrm{CuCl}_{2}$ in $100 \mathrm{l}$ of tap water. The experimental treatments (fig. 1B) consisted of 2 ten-day periods of $\mathrm{N}$ deprivation which started 18 and 28 days after sowing. These treatments were called hereafter treatments 2.1 and 2.2 , respectively.

\section{Experiment 3}

This experiment was conducted in 1982 at the Agronomy Station, Colmar, France, as described previously (GIRARDIN et al., 1985b) (fig. 1C). Nitrogen was withheld from treatment plants on $42 \mathrm{nd}, 77 \mathrm{th}, 88 \mathrm{th}$ and 98 th day after sowing for respectively a period of 14 , 21,41 and 21 days. These treatments are hereafter referred to as treatments $3.1,3.2,3.3,3.4$.

\section{Harvest procedures and notations}

In experiment 1, 2 plants were harvested from each treatment at the end of $\mathrm{N}$ deprivation and, for treatments 1.1 and $1 . \mathrm{C}$ at the 18th, 22nd, 25th, 28th, $38 \mathrm{th}, 49 \mathrm{th}, 58 \mathrm{th}, 68 \mathrm{th}$ day after planting (fig. 1A). The last harvest occurred at physiological maturity of the control plants, and 5 plants were harvested for all the $\mathrm{N}$ treatments. In experiments 2 and 3, 32 and 4 plants were used, respectively, for dry matter determination at physiological maturity. All the plant samples were oven-dried at $80^{\circ} \mathrm{C}$ for 3 days. Leaf stage was estimated according to TOLLENAAR \& HUNTER (1983), by partitioning leaf stages into $\mathrm{n}, \mathrm{n}+0.25, \mathrm{n}+0.50$, $\mathrm{n}+0.75$ (i.e., the $\mathrm{n}^{\text {th }}$ leaf stage is the phenological stage at which the tip of the $\mathrm{n}^{\text {th }}$ leaf is just visible in the whorl). The leaves were numbered from the bottom to the top. The length and the maximum width of all leaves on all plants were measured weekly for experiments 1 and 3 ; leaf area index (LAI) was calculated by summing the measured leaf area per plant (length $\times$ max. width $\times 0.73$; MCKEE, 1964) and dividing by the corresponding ground area. The extrusion of silks from the ears was recorded individually for each plant. 
A

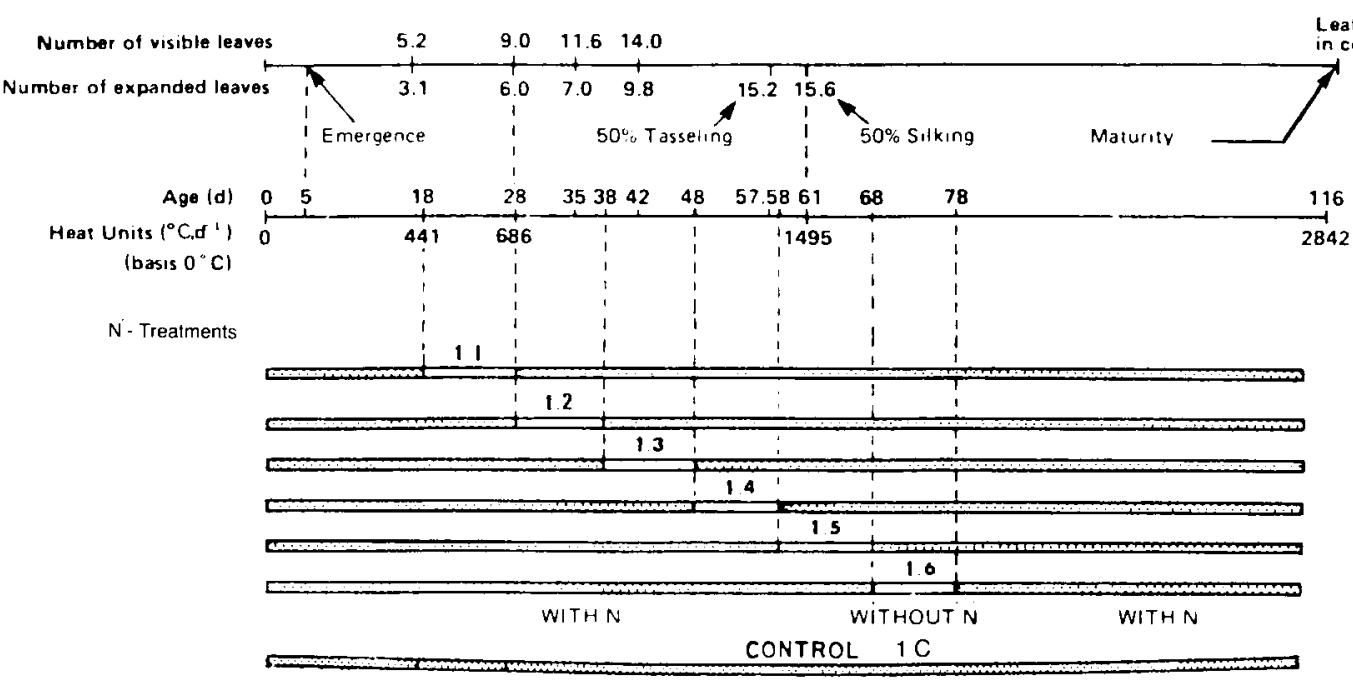

日

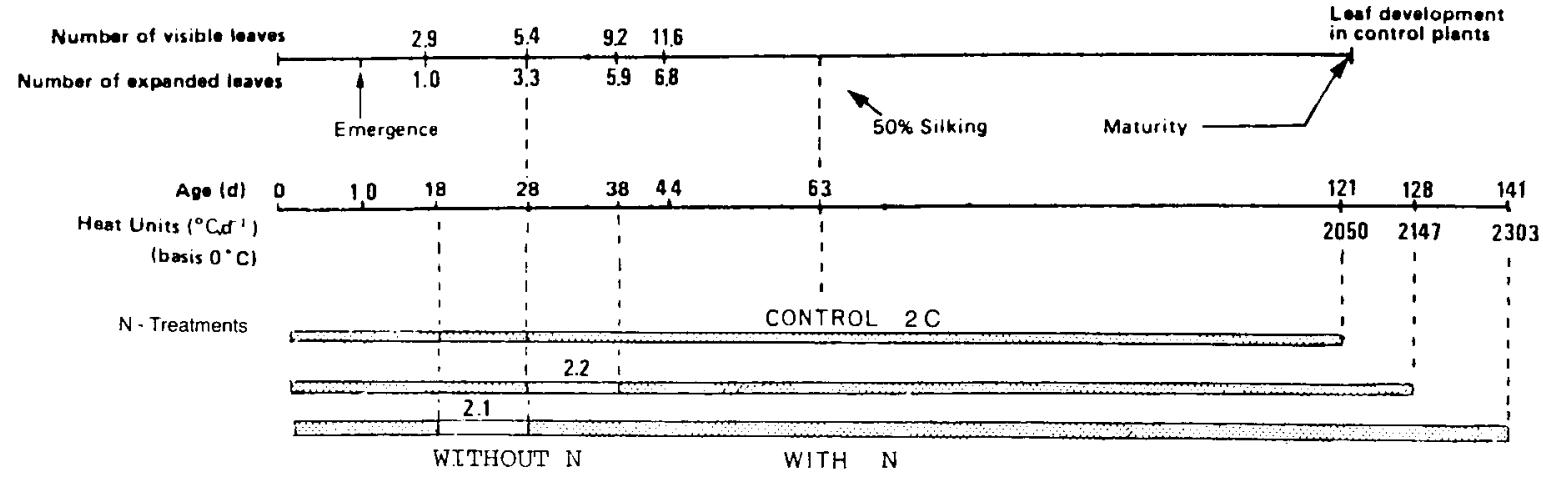

C

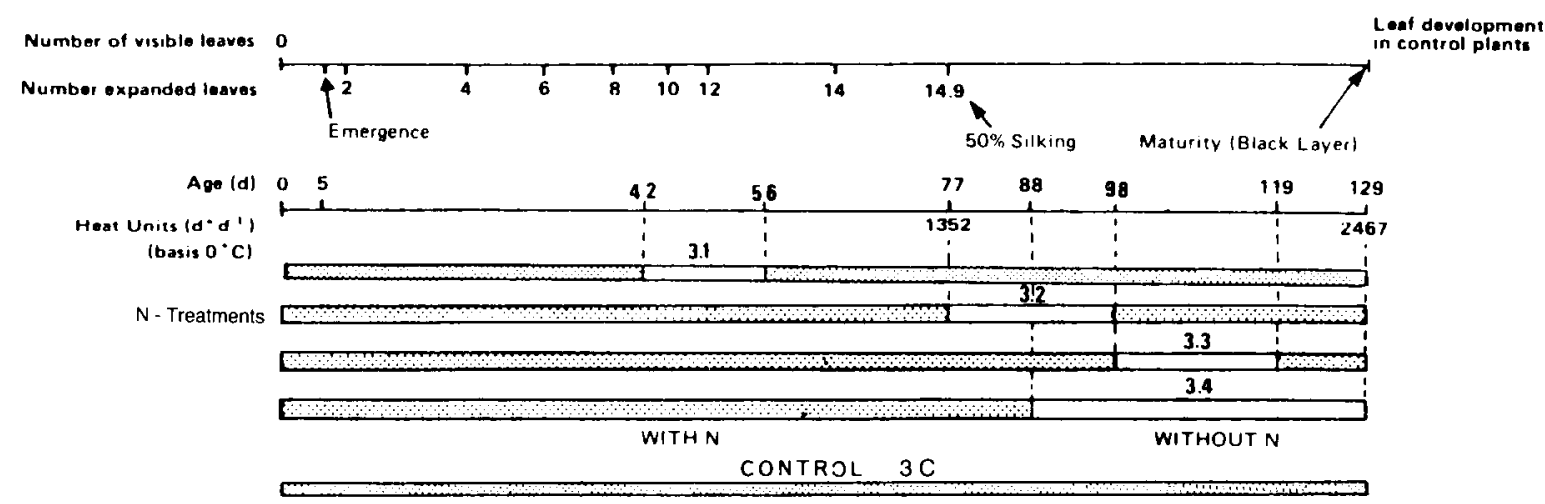

Figure 1

Experimental design :

(A) Experiment I (growthroom),

(B) Experiment 2 (plants in pails outdoors),

(C) Experiment 3 (plants in pails outdoors).

Schéma des expériences :

(A) Expérience 1 (chambre de culture),

(B) Expérience 2 (plantes en pots à l'extérieur),

(C) Expérience 3 (plantes en pots à l'extérieur). 
Node number was recorded as follows : "0" corresponded with the coleoptile node, "1", corresponded with the first leaf. A root was considered elongated when it pierced the epidermis. A root was considered as initiated when it was visible under the epidermis at the lower part of the node. The control treatments in the 3 experiments (i.e., no $\mathrm{N}$ deprivation during the experimental period) are referred to as $1 \mathrm{C}$, $2 \mathrm{C}$ and $3 \mathrm{C}$ for experiment 1,2 and 3 , respectively.

\section{RESULTS}

$\mathrm{N}$ deprivation did not have any effect on most parameters of plant development (table 1). The total number of leaves at silking was not different between treatments, the number of tassel branches was similar for all the $\mathrm{N}$ deprived plants though the first $\mathrm{N}$ deprivation (1.1) occurred during the last period of leaf initiation and at the beginning of tassel initiation. The ear leaf number was similar for all treatments even though the ear initiation occurred during a $\mathrm{N}$-starvation period (1.2). In experiment $1, \mathrm{~N}$ withdrawal from nutrient solution delayed silking, particularly in the earliest treatment. Generally, $N$ starvation affected silking to a greater degree than tasseling. The root number is different between the $\mathrm{N}$-starved plants and the control plants only for the early nitrogen deprivation and the upper nodes : nodes 5, 6 and 7 for treatment 1.1 , nodes 6 and 7 for treatment 1.2 , node 7 for treatment 1.3 (table 2). The total elongated root number per plant and the last node with elongated roots were not significantly different between $\mathrm{N}$ treatments. Treatments 1.1 and 3.1 induced a decrease in total leaf area of respectively 19 and $25 \%$ relative to the control plants (table 3 ). For other $\mathrm{N}$ treatments there was no significant effect on leaf area.

A detailed study of growth and development parameters was made for treatment 1.1 and 1.C (table 4).

TABLE 1

Developmental characteristics of $\mathrm{N}$-deficient and control plants in Experiments 1 and 3.

Caractéristiques des paramètres de développement pour les plantes témoins et les plantes déficientes en azote (exp. I et 3).

\begin{tabular}{|c|c|c|c|c|c|}
\hline \multirow{2}{*}{ Treatments } & \multirow{2}{*}{$\begin{array}{c}\text { Total leaf } \\
\text { number }\end{array}$} & \multicolumn{2}{|c|}{ Duration of development periods } & \multirow{2}{*}{$\begin{array}{c}\text { Number of } \\
\text { tassel branches }\end{array}$} & \multirow{2}{*}{$\begin{array}{l}\text { Ear lea } \\
\text { number }\end{array}$} \\
\hline & & Sowing silking & Anthesis silking & & \\
\hline \multicolumn{6}{|c|}{$-------\mathrm{d}----$} \\
\hline 1.1 & $15.4^{\mathrm{a}}$ & $71.7^{\mathrm{b}}$ & $14.0^{\mathrm{d}}$ & $10.2^{\mathrm{f}}$ & $10.6^{\mathrm{g}}$ \\
\hline 1.2 & $16.0^{\mathrm{a}}$ & $64.2^{\mathrm{c}}$ & $5.5^{\mathrm{e}}$ & $11.6^{\mathrm{f}}$ & $10.8^{g}$ \\
\hline 1.3 & $15.8^{\mathrm{a}}$ & $60.5^{c}$ & $3.8^{\mathrm{e}}$ & $11.6^{\mathrm{f}}$ & $11.0^{\mathrm{g}}$ \\
\hline 1.4 & $15.4^{\mathrm{a}}$ & $64.3^{\mathrm{c}}$ & $3.3^{\mathrm{e}}$ & $10.4^{f}$ & $10.6^{\mathrm{g}}$ \\
\hline 1.5 & $15.8^{\mathrm{a}}$ & $59.0^{\mathrm{c}}$ & $3.0^{\mathrm{e}}$ & $11.4^{\mathrm{f}}$ & $11.0^{\mathrm{g}}$ \\
\hline 1.6 & $16.0^{\mathrm{a}}$ & $61.8^{\mathrm{c}}$ & $4.2^{\mathrm{e}}$ & $10.3^{\mathrm{f}}$ & $10.6^{\mathrm{g}}$ \\
\hline 1.C & $16.0^{\mathrm{a}}$ & $59.8^{\mathfrak{c}}$ & $3.5^{\mathrm{e}}$ & $11.6^{\mathrm{f}}$ & $10.8^{\mathrm{g}}$ \\
\hline 3.1 & $14.8^{\mathrm{h}}$ & $76.2^{\mathrm{i}}$ & $5.7^{\mathrm{j}}$ & $11.3^{\mathrm{k}}$ & - \\
\hline 3.C & $14.9^{\mathrm{h}}$ & $76.4^{i}$ & $4.7^{\mathrm{j}}$ & $11.4^{k}$ & - \\
\hline
\end{tabular}

- Number followed by the same letter in a column were not significantly different $(p=0.05)$.

- Les chiffres suivis d'une même lettre, dans une colonne, ne sont pas significativement différents (au seuil $5 \%$ ).

TABLE 2

Root development of $\mathrm{N}$-deficient and control plants at final harvest.

Développement racinaire des plantes témoins et des plantes déficientes en azote à maturité (exp. 1).

\begin{tabular}{|c|c|c|c|c|c|c|c|}
\hline $\begin{array}{c}\text { Node } \\
\text { number }\end{array}$ & 1.1 & 1.2 & 1.3 & $\begin{array}{c}\text { Treatments } \\
1.4\end{array}$ & 1.5 & 1.6 & 1.C \\
\hline & $\cdots-\cdots$ & $-\ldots$ & - tota & ed root num & hode - & --- & -- \\
\hline 1 & $4.0^{\mathrm{a}}$ & $3.8^{\mathrm{a}}$ & $4.0^{\mathrm{a}}$ & $3.8^{\mathrm{a}}$ & $4.0^{\mathrm{a}}$ & $4.0^{\mathrm{a}}$ & $3.8^{\mathrm{a}}$ \\
\hline 2 & $4.0^{\mathrm{b}}$ & $4.0^{\mathrm{b}}$ & $3.8^{\mathrm{b}}$ & $3.8^{\mathrm{b}}$ & $4.2^{\mathrm{b}}$ & $3.6^{\mathrm{b}}$ & $3.6^{\mathrm{b}}$ \\
\hline 3 & $3.6^{\mathrm{c}}$ & $3.2^{\mathrm{cd}}$ & $3.6^{\mathrm{c}}$ & $3.0^{\mathrm{d}}$ & $3.8^{\mathrm{c}}$ & $3.2^{\mathrm{c}}$ & $3.8^{\mathrm{c}}$ \\
\hline 4 & $5.0^{\mathrm{e}}$ & $4.2^{\mathrm{ef}}$ & $5.0^{\mathrm{e}}$ & $4.6^{\mathrm{e}}$ & $5.4^{\mathrm{e}}$ & $4.2^{\mathrm{f}}$ & $5.0^{\mathrm{e}}$ \\
\hline 5 & $9.2^{\mathrm{g}}$ & $9.6^{\mathrm{gh}}$ & $10.0^{\mathrm{gh}}$ & $11.0^{\mathrm{gh}}$ & $10.4^{g h}$ & $10.0^{\mathrm{gh}}$ & $11.2^{\mathrm{h}}$ \\
\hline 6 & $13.2^{\mathrm{i}}$ & $13.0^{\mathrm{i}}$ & $13.6^{\mathrm{ij}}$ & $14.0^{\mathrm{ij}}$ & $13.4^{i j}$ & $13.6^{\mathrm{i} \mathrm{j}}$ & $14.8^{\mathrm{j}}$ \\
\hline \multirow[t]{5}{*}{7} & $15.4^{\mathrm{k}}$ & $15.0^{\mathrm{k}}$ & $16.0^{k}$ & $18.4^{1}$ & $18.2^{1}$ & $16.6^{\mathrm{kl}}$ & $17.4^{\mathrm{l}}$ \\
\hline & ---- & --- & $--e$ & root numbe & $\mathrm{nt}-$ & --- & -- \\
\hline & $\begin{array}{l}28.2 \\
(8.3)\end{array}$ & $\begin{array}{l}35.4 \\
(6.6)\end{array}$ & $\begin{array}{l}29.8 \\
(4.8)\end{array}$ & $\begin{array}{l}34.8 \\
(6.7)\end{array}$ & $\begin{array}{l}32.0 \\
(5.4)\end{array}$ & $\begin{array}{l}30.4 \\
(5.3)\end{array}$ & $\begin{array}{l}36.6 \\
(8.4)\end{array}$ \\
\hline & ---- & -- & -- & with elong & $s--$ & --- & -- \\
\hline & 4.4 & 5.4 & 4.8 & 4.8 & 4.4 & 4.8 & 4.8 \\
\hline
\end{tabular}

- ( ) Standard error - Ecart-type.

- Numbers followed by the same letter in a row were not significantly different $(\mathrm{p}=0.05)$.

- Les chiffres suivis d'une même lettre, dans une colonne, ne sont pas significativement différents (au seuil $5 \%$ ). 
TABLE 3

Leaf area index of $\mathrm{N}$-deficient and control plants at silking.

Indice de surface foliaire des plantes témoins et des plantes déficientes en azote à la floraison.

\begin{tabular}{ccccccccccc}
\hline & \multicolumn{1}{c}{ Exp. 1 } & & & & Exp. 3 \\
\cline { 2 - 10 } & 1.1 & 1.2 & 1.3 & 1.4 & 1.5 & 1.6 & $1 . C$ & 3.1 & $3 . \mathrm{C}$ \\
\hline \multirow{2}{*}{ LAI } & 3.5 & 4.1 & 4.2 & 3.9 & 4.5 & 4.7 & 4.3 & 3.3 & 4.3 \\
& $(0.59)$ & $(0.30)$ & $(0.39)$ & $(0.46)$ & $(0.58)$ & $(0.40)$ & $(0.38)$ & $(0.43)$ & $(0.55)$ \\
\hline
\end{tabular}

( ) Standard error - Ecart-type.

TABLE 4

Green leaf area, leaf appearance rate,

root (R) and shoot (S) dry matter (DM), CGR and RGR of control (I.C) and N-deficient (1.1) plants.

Surface foliaire verte, taux d'apparition des feuilles, matière sèche racinaire et aérienne, CGR et RGR des plantes témoins (1.C), et des plantes déficientes en azote (1.1).

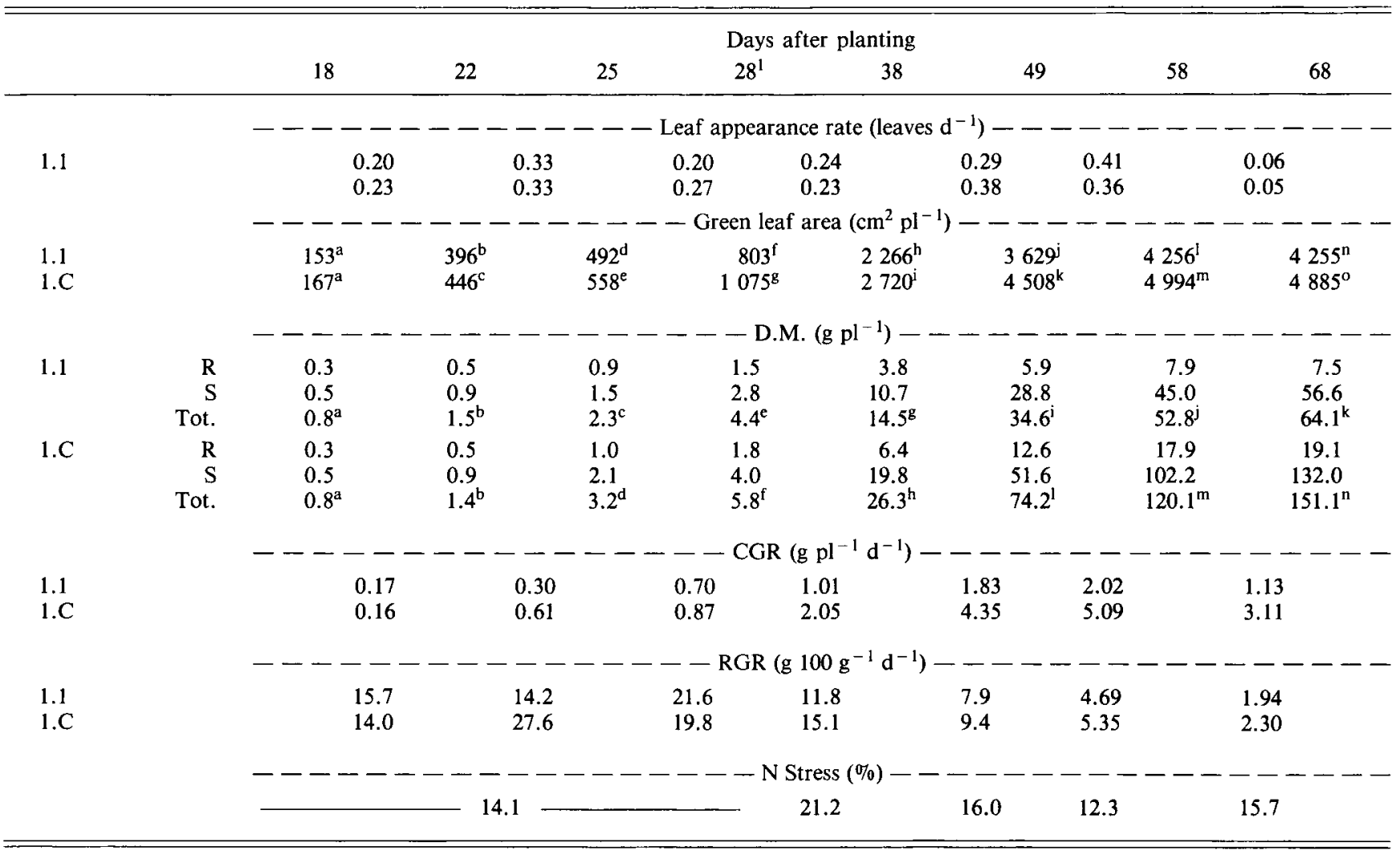

- 1 End of the 10 day nitrogen deprivation.

- Numbers followed by the same letter were not significantly different $(p=0.05)$.

- Fin de la période de 10 jours sans azote.

- Les chiffres suivis par une même lettre dans une colonne ne sont pas significativement différents (au seuil $5 \%$ ).

Leaf appearance rate (which is in fact a parameter of both development and dry matter accumulation since it depends first on leaf elongation and later on stem elongation) was not affected by $\mathrm{N}$ starvation (trt. 1.1). In contrast, green leaf area of $\mathrm{N}$-deprived plants was $25 \%$ lower than that of control plants at the end of the $\mathrm{N}$-deficiency period. During the $\mathrm{N}$ starvation period the dry matter accumulation was lower in $\mathrm{N}$ deprived plants than in control plants, particularly for the above-ground parts. The root/shoot ratio did not drop as quickly in $\mathbf{N}$ starved plants as in plants which were well supplied with nitrogen (fig. 2). The effect of $\mathrm{N}$ starvation was noticeable during several of the 10day periods after resupplying plants with nitrogen : the crop growth rate $\left(\mathrm{CGR}=\frac{\mathrm{W}_{2}-\mathrm{W}_{1}}{\mathrm{t}_{2}-\mathrm{t}_{1}}\right)$ was about 50 per cent lower in $\mathrm{N}$ deprived than in control plants, the relative growth rate $\left(R G R=\frac{1_{n} W_{2}-1_{n} W_{1}}{t_{2}-t_{1}}\right)$ was also affected just after the $\mathrm{N}$ deprived period (Table 4). The effect was larger after than during the $\mathrm{N}$ deprivation period. The nitrogen stress, calculated according to Greenwood (1976), $\left(\frac{\mathrm{RGR}_{\mathrm{Ndeprived}}-\mathrm{RGR}_{\text {control }}}{\mathrm{RGR}_{\text {control }}}\right)$ was only 14.1 per cent during the $\mathrm{N}$ withdrawal from nutrient solution. After 


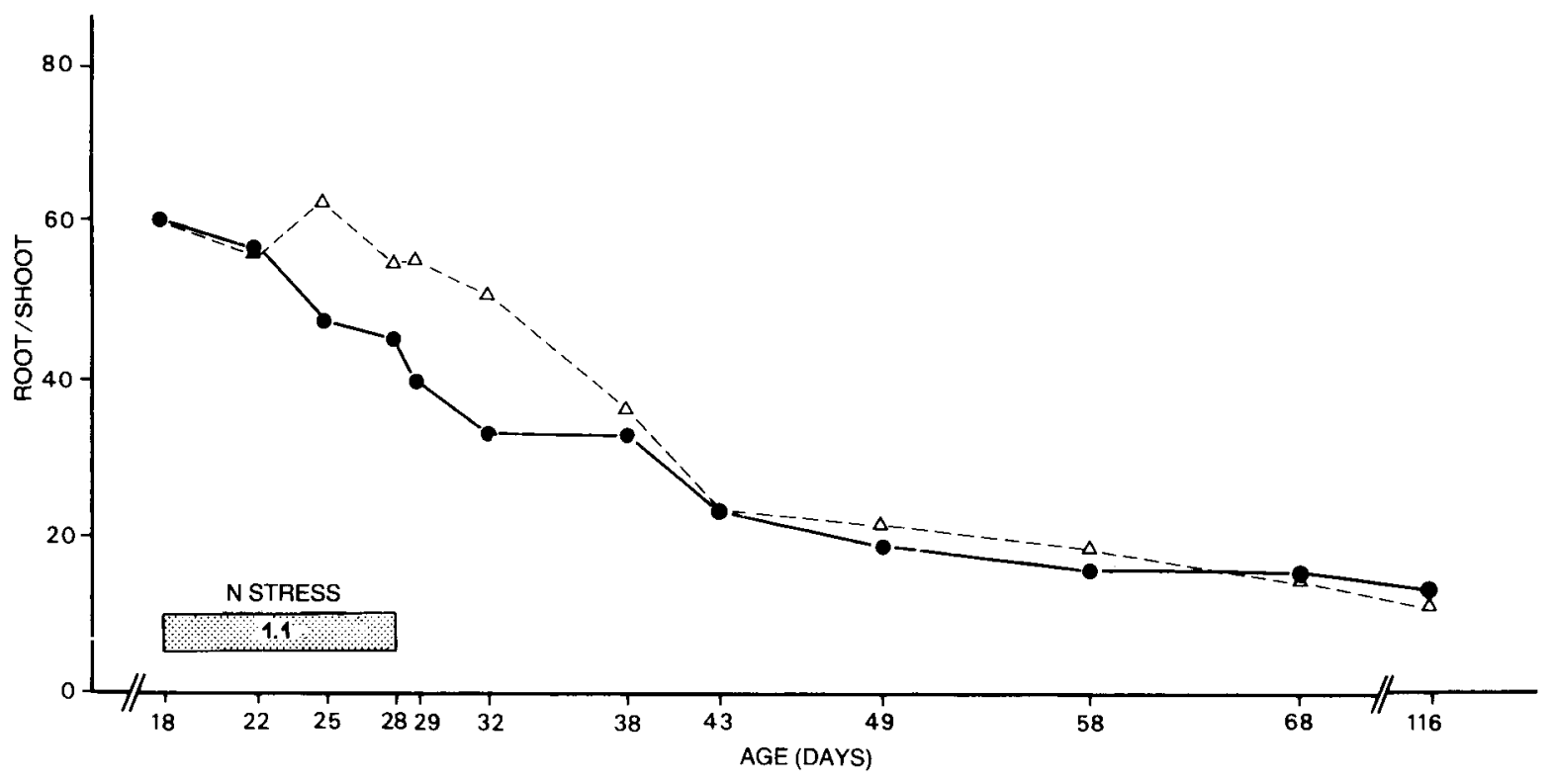

Figure 2

Root/Shoot dry matter ratio vs. plant age (treatment 1.1: $\triangle-\cdots \triangle$ ) (control -).

Rapport matière sèche racinaire sur matière sèche aérienne en fonction de l'âge de la plante (traitement $1.1: \Delta \cdots \triangle$ ) (traitement $1 . C$ :

$\bullet-\bullet$.

resupplying plants with nitrogen, the percent of stress became $21.2,16.0,12.3$ and 15.7 per cent, respectively during the first, second, third and four 10-day period after the end of $\mathrm{N}$ starvation.

The results of 1st treatment (1.1), recorded at final harvest were discarded, because of a too important standard error on the D.M. of treated plants. The influence of $\mathrm{N}$ starvation on dry matter yield was much as expected (table 5), early $\mathrm{N}$ deprivations having the greatest influence. When a 10-day nitrogen starvation began 18 days after sowing, grain yield was $50 \%$ of that of control plants, but total dry matter yield was less affected ( $25 \%$ lower than the control). These data found expression in harvest index values which were low for the early $\mathrm{N}$ treatments, but were similar to normal field-grown maize for the control. The most affected yield component was the number of grains per plant, but $\mathrm{N}$ deprivation before silking also produced a lower 1000-grain weight relative to the control. Number of rows per ear was not influenced by any $\mathrm{N}$ starvation treatment. The differences in grain moisture content between treatments were characteristic of a delay in maturity which could explain in part the low grain yield of early $\mathrm{N}$-starved plants. In experiment 2 , there was no difference between treatments but maturity occurred later than the control in treatment 2.1 .

TABLE 5

Dry matter yield and yield components for each $\mathrm{N}$-treatment at final harvest in three experiments. Rendement en matière sèche et composantes du rendement pour chaque traitement azoté à maturité (exp. 1-2-3).

\begin{tabular}{|c|c|c|c|c|c|c|c|c|}
\hline \multicolumn{9}{|c|}{ Dry matter } \\
\hline & Grain & Roots & Total & $\begin{array}{l}\text { Harvest } \\
\text { index }\end{array}$ & $\begin{array}{c}1000 \text {-grain } \\
\text { weight* }\end{array}$ & $\begin{array}{c}\mathrm{Nb} \text { grains/ } \\
\text { plant }\end{array}$ & $\begin{array}{c}\text { Nb rows/ } \\
\text { ear }\end{array}$ & $\begin{array}{c}\text { Grain } \\
\text { moisture }\end{array}$ \\
\hline & ---- & $\mathrm{g} \mathrm{pl}^{-1}$ & --- & & $--g--$ & & & $--\%--$ \\
\hline 1.2 & $67.0^{\mathrm{a}}$ & $11.5^{\mathrm{bc}}$ & $191.5^{\mathrm{ab}}$ & $0.37^{\mathrm{a}}$ & $248.1^{\mathrm{a}}$ & $270^{\mathrm{a}}$ & $13.2^{\mathrm{a}}$ & $41.1^{\mathrm{b}}$ \\
\hline 1.3 & $88.8^{\mathrm{ab}}$ & $9.8^{\mathrm{a}}$ & $202.6^{\mathrm{bc}}$ & $0.46^{\mathrm{b}}$ & $251.3^{\mathrm{a}}$ & $354^{b}$ & $12.8^{\mathrm{a}}$ & $39.9^{\mathrm{b}}$ \\
\hline 1.4 & $65.1^{\mathrm{a}}$ & $10.7^{\mathrm{ab}}$ & $175.7^{\mathrm{a}}$ & $0.39^{\mathrm{a}}$ & $250.1^{\mathrm{a}}$ & $260^{a}$ & $12.4^{\mathrm{a}}$ & $41.8^{\mathrm{b}}$ \\
\hline 1.5 & $98.1^{\mathrm{b}}$ & $10.9^{\mathrm{ab}}$ & $220.1^{b c}$ & $0.47^{\mathrm{b}}$ & $250.3^{\mathrm{a}}$ & $392^{\mathrm{b}}$ & $13.8^{\mathrm{a}}$ & $36.1^{\mathrm{a}}$ \\
\hline 1.6 & $101.1^{\mathrm{b}}$ & $13.2^{\mathrm{c}}$ & $236.9^{c}$ & $0.45^{\mathrm{b}}$ & $263.2^{\mathrm{b}}$ & $384^{\mathrm{b}}$ & $12.0^{\mathrm{a}}$ & $36.4^{\mathrm{ab}}$ \\
\hline 1.C & $103.4^{\mathrm{b}}$ & $13.3^{\mathrm{c}}$ & $244.3^{c}$ & $0.45^{\mathrm{b}}$ & $270.4^{\mathrm{b}}$ & $382^{b}$ & $13.2^{\mathrm{a}}$ & $35.9^{\mathrm{a}}$ \\
\hline 2.1 & $108.3^{\mathrm{c}}$ & $14.2^{\mathrm{d}}$ & $221.7^{\mathrm{d}}$ & $0.48^{d}$ & $276.0^{c}$ & $392^{c}$ & - & $36.8^{\mathrm{c}}$ \\
\hline 2.2 & $114.3^{c}$ & $20.9^{\mathrm{e}}$ & $247.4^{\mathrm{e}}$ & $0.51^{\mathrm{d}}$ & $264.5^{\mathrm{c}}$ & $432^{c}$ & - & $38.9^{\mathrm{c}}$ \\
\hline 2.C & $104.8^{c}$ & $19.8^{\mathrm{e}}$ & $261.9^{e}$ & $0.44^{c}$ & $248.3^{\mathrm{c}}$ & $422^{\mathrm{c}}$ & - & $36.5^{\mathrm{c}}$ \\
\hline 3.1 & $33.2^{\mathrm{d}}$ & $11.2^{\mathrm{f}}$ & $133.9^{f}$ & $0.27^{\mathrm{e}}$ & $157.5^{\mathrm{d}}$ & $211^{\mathrm{d}}$ & $10.0^{\mathrm{a}}$ & $37.6^{e}$ \\
\hline 3.2 & $82.7^{\mathrm{f}}$ & $12.1^{\mathrm{f}}$ & $171.7^{\mathrm{g}}$ & $0.52^{\mathrm{f}}$ & $253.3^{\mathrm{e}}$ & $326^{e}$ & $13.0^{\mathrm{ab}}$ & $36.2^{\mathrm{e}}$ \\
\hline 3.3 & $53.3^{\mathrm{e}}$ & $8.3^{\mathrm{f}}$ & $115.2^{\mathrm{f}}$ & $0.50^{\mathrm{f}}$ & $188.8^{\mathrm{d}}$ & $282^{\mathrm{e}}$ & $11.8^{\mathrm{ab}}$ & $27.9^{f}$ \\
\hline 3.4 & $51.5^{\mathrm{e}}$ & $10.8^{\mathrm{f}}$ & $122.2^{\mathrm{f}}$ & $0.46^{\mathrm{f}}$ & $228.9^{\text {de }}$ & $225^{\mathrm{d}}$ & $12.5^{\mathrm{ab}}$ & $39.5^{\mathrm{e}}$ \\
\hline $3 . \mathrm{C}$ & $66.8^{\text {ef }}$ & $10.3^{f}$ & $160.1^{\mathrm{g}}$ & $0.45^{\mathrm{f}}$ & $219.7^{\mathrm{de}}$ & $304^{\mathrm{e}}$ & $13.5^{\mathrm{b}}$ & $35.8^{\mathrm{e}}$ \\
\hline
\end{tabular}

\footnotetext{
* Grain at $15 \%$ moisture.
}

Grain à $15 \%$ d'humidité. 
The failure of the $\mathrm{N}$ deprivation treatments to affect total kernel number in this experiment, however, cannot be attributed to a delay in maturity.

\section{DISCUSSION}

Most parameters of plant development were not significantly affected by $\mathrm{N}$ treatments, even if the treatments occurred during the initiation of new organs. The developing tissues were the last to be influenced by $\mathrm{N}$ withdrawal from nutrient solution. The only consequence of $\mathrm{N}$ deprivation on plant development was a delay in silking for the earliest treatments. The $\mathrm{N}$ starvation effect on the number of roots of 5 th, 6 th and 7 th nodes could be only a secondary effect caused by a reduction in diameter of the lower stem. For a young maize plant, first leaves have a small "buffer capacity" for nitrogen, so the yellowing of these old leaves occurs rapidly following a period of $\mathrm{N}$ deficiency (GIRARDIN et al., 1985b). On these young plants the leaf growth is strongly influenced by $\mathrm{N}$ as shown by the LA values of the 1.1 treatment (table 3 ). The larger difference in CGR than RGR towards the end of experiment 1 is attribuable to the diverging values of plant weight $(\mathrm{W})$, since $\mathrm{CGR}=\mathrm{RGR} \times \mathrm{W}$. Total dry matter is more affected than the leaf area by a $\mathrm{N}$ deficiency (respectively $58 \%$ and $19 \%$ decrease relative to the control at silking for treatment 1.1 ). BROUWER (1983) emphasizes this discrepancy between growth in dry matter and growth in "exposed area". The use of simulation models has shown the consequences on dry matter production of a small change in leaf area in the earliest developmental stages (GIRARDIN, 1982).

The lack of response of most plant growth and development parameters to $\mathrm{N}$ deprivation in mature and old maize plants might be due to a "buffer effect" of the stem and old leaves to low nitrogen. $\mathrm{N}$ translocation from the lower stem and old leaves compensates in part the lack of $\mathrm{N}$ supply and it occures earlier than normal under $\mathrm{N}$ deficient conditions (HANWAY, 1962). The root/shoot ratio is greatly influenced by nitrogen deprivation. The balance between root or shoot depends upon whether shoot- or root supplied factors are more limiting at that point in time. Roots have first priority in use of the nutrient supply, largely because of their proximity to a source of nitrogen (BROUWER \& LOEN, 1962 ; EDWARDS \& BARBER, 1976 ; CALOUIN et al., 1980). BOOTE (1977) explains the higher ratio of roots to shoots by the high sugar levels in the roots of $\mathrm{N}$ deficient plants which presumably increase root growth. After 10 days of $\mathrm{N}$ resupply the root/shoot ratio became similar in $\mathrm{N}$-deficient and control plants. Another explanation may be that maximum root growth occurs at lower nitrogen levels than those for shoot growth (LEMAIRE, 1975).

Differences in grain yield between $\mathrm{N}$ treatments were associated with differences in final total plant dry weight and, to some extent, to differences in partitioning of dry matter to the grain, as indicated by harvest index (table 5). A lower harvest index may, in part, be attributed to a delay in maturity (i.e., grain moisture content of the grain). In experiment 2 , contrary to harvest index, grain moisture content was affected by $\mathrm{N}$ treatment, although maturity occurred up to 3 weeks later for the $\mathrm{N}$-deprivation treatments (fig. 1B). $\mathrm{N}$ deprivation treatments just before or after silking did not affect grain yield, which may be the result of a "buffering"' effect of stems and leaves on $\mathrm{N}$ deprivation. These results are in accordance with results reported by FRIEDRICH et al. (1979), which also showed no effect of nitrogen deprivation during the grain filling period on grain yield. Among the yield components, grain number and grain weight, appeared to be affected by the $\mathrm{N}$-starvation treatments contrary to number of rows. The discrepancy with respect to grain number between the results of experiments 1 and 3 on the one hand, and experiment 2 on the other hand, is notable and unexplainable to us, but indicates a $\mathrm{N} \times$ environment interaction for kernel number.

In contrast to water deprivation which has large effects on maize plants when it occurs during the silking period, nitrogen deprivation induces changes on plant growth especially when $\mathrm{N}$ deficiency occurs early (before the sixth leaf stage). This can be explained by the weak "buffer effect" of the maize plant, during early developmental stages for nitrogen, and, at silking time for water.

In conclusion, at the first development stages, $\mathrm{N}$ requirements of maize plants are not large, but, if nitrogen is not available at this time, maturity is delayed up to 3 weeks and the consequences can be drastic. In contrast, $\mathrm{N}$ deficiency just after silking is of no consequence to grain yield, apparently due to $\mathrm{N}$ remobilization from the stem and old leaves. Consequently, it seems $\mathrm{N}$ fertilization during the silking period (by means "fertigation", for example), has not to be recommended. In the same way, it is necessary to apply about $30 \mathrm{~N}$ to cover the imperious $\mathrm{N}$ requirements in early developmental stages of maize.

Reçu le 19 mars 1986 Accepté le 19 janvier 1987.

\section{REFERENCES}

Anderson C. K., Stone L. R., Murphy L. S., 1982. Corn yield as influenced by in-season application of nitrogen with limited irrigation. Agron. J., 74, 396-401.

Bigeriego M., Hauck R. D., Olson R. A., 1979. Uptake, translocation and utilization of ${ }^{15} \mathrm{~N}$-depleted fertilizer in irrigated Corn. Soil Sci. Soc. Am. J., 43, 528-533.

Boote K. J., 1977. Root : shoot relationships. Proc. Soil Crop. Sci. Soc. Flo., 36, 15-23.
Brouwer R., 1983. Functional equilibrium : sense or nonsense ? Neth. J. agric. Sci., 31, 335-348.

Brouwer R., Loen E. A., 1962. Growth and uptake of individual crown roots of maize. Jaarb. Inst. Biol. Scheikd. Onderz. Landbowgewassen, 1962, 19-25.

Calouin N., El Khodre A., Atry M., 1980. Effect of nitrate concentration at the root/shoot ratio in Dactylis glomerata $\mathrm{L}$. and on the kinetics of growth in the vegetative phase. Ann. Bot., 46, 165173. 
Carles J., Soubies L., Gadet R., 1957. Influence d'une fourniture plus ou moins abondante d'engrais azotés sur la pénétration et la migration des éléments minéraux chez le maïs. C. R. Acad. Agric. Fr., 43, 536-544.

Edwards J. H., Barber S. A., 1976. Nitrogen uptake characteristics of corn roots at low $\mathrm{N}$ concentration as influenced by plant age. Agron. J., 68, 17-19.

Friedrich J. W., Schrader L. E., Nordheim E. W., 1979. N deprivation in maize during grain filling : I. Accumulation of dry matter, nitrate-N and sulfate-S. Agron. J., 71, 461-465.

Girardin Ph., 1982. Essais de modélisation de la croissance et du développement du maïs-grain (Zea mays L.). Thèse de Doct.-Ing. Univ. de Paris Sud, 142 p.

Girardin Ph., Tollenaar M., Muldoon J. F., 1985a. Effects of temporary $\mathrm{N}$ starvation in maize on leaf photosynthetic rate and chlorophyll content. Can. J. Plant Sci., 65, 491-500.

Girardin Ph., Tollenaar M., Deltour A., 1985b. Effects of temporary $\mathrm{N}$ starvation in maize on leaf senescence. Can. J. Plant Sci., 65, 819829.

Greenwood E. A. N., 1976. Nitrogen stress in plants. Adv. Agron., 28, 1-35.

Hanway J. J., 1962. Corn growth and composition in relation to soil fertility : II. Uptake of N, P and $\mathrm{K}$ and their distribution in different plant parts during the growing season. Agron. J., 54, 217-222.

Lemaire F., 1975. Action comparée de l'alimentation azotée sur la croissance du système racinaire et des parties aériennes des végétaux. Ann. agron., 26, 59-74.

McKee G. W., 1964. A coefficient for computing leaf area in hybrid corn. Agron. J., 56, 240-241.
Miller H. F., Kavanaugh J., Thomas G. W., 1975. Time of N application and yields of corn in wet, alluvial soils. Agron. J., 67, 401-404.

Olson R. A., Dreier A. F., Thompson C., Frank K., Grabouski P. H., 1964. Using fertilizer nitrogen effectively on grain crops. Nebr. agric. Exp. Stn., 479, 10-14.

Olson R. A., Frank K. D., Deibert E. J., Dreier A. F., Sander D. H., Johnson V. A., 1976. Impact of residual mineral $\mathbf{N}$ in soil on grain protein yields of winter wheat and corn. Agron. J., 68, 769-772.

Power J. F., 1971. Evaluation of water and nitrogen stress on bromegrass growth. Agron. J., 63, 726-728.

Rémy J.-C., Viaux P., 1983. La fertilisation azotée du blé tendre en système intensif en France. Perspect. agric., 67, 26-34.

Stevenson C. K., Baldwin C. S., 1969. Effect of time and method of nitrogen application and source of nitrogen on the yield and nitrogen content of corn (Zea mays L.). Agron. J., 61, 381-384.

Thom E. R., Watkin B. R., 1978. Effect of rate and time of fertilizer nitrogen application on total plant, shoot and root yields of maize (Zea mays L.). N.Z. J. Exp. Agric., 6, 29-38.

Tollenaar M., Hunter R. B., 1983. A photoperiod and temperature sensitive period for leaf number of maize. Crop. Sci., 23, 457-460.

Tollenaar M., Migus W., 1984. Dry matter accumulation of maize grown hydroponically under controlled-environment and field conditions. Can J. Plant Sci., 64, 475-485.

Viets F. G., 1965. The plant's need for and use of nitrogen, p. $503-$ 549. In : Bertholomev. Soil Nitrogen. Academic Press, New York.

Welch L. F., Mulvaney D. L., Oldham M. G., Boone L. V., Pendleton J. W., 1971. Corn yields with fall, spring and sidedress nitrogen. Agron. J., 63, 119-123. 